This item was submitted to Loughborough's Research Repository by the author.

Items in Figshare are protected by copyright, with all rights reserved, unless otherwise indicated.

\title{
(Re)civilizing the young driver: technization and emotive automobility
}

\section{PLEASE CITE THE PUBLISHED VERSION}

http://dx.doi.org/10.1080/17450101.2013.823716

\section{PUBLISHER}

(C) Taylor \& Francis (Routledge)

\section{VERSION}

AM (Accepted Manuscript)

\section{LICENCE}

CC BY-NC-ND 4.0

\section{REPOSITORY RECORD}

Lumsden, Karen. 2019. "(re)civilizing the Young Driver: Technization and Emotive Automobility". figshare. https://hdl.handle.net/2134/13257. 
This item was submitted to Loughborough's Institutional Repository (https://dspace.lboro.ac.uk/) by the author and is made available under the following Creative Commons Licence conditions.

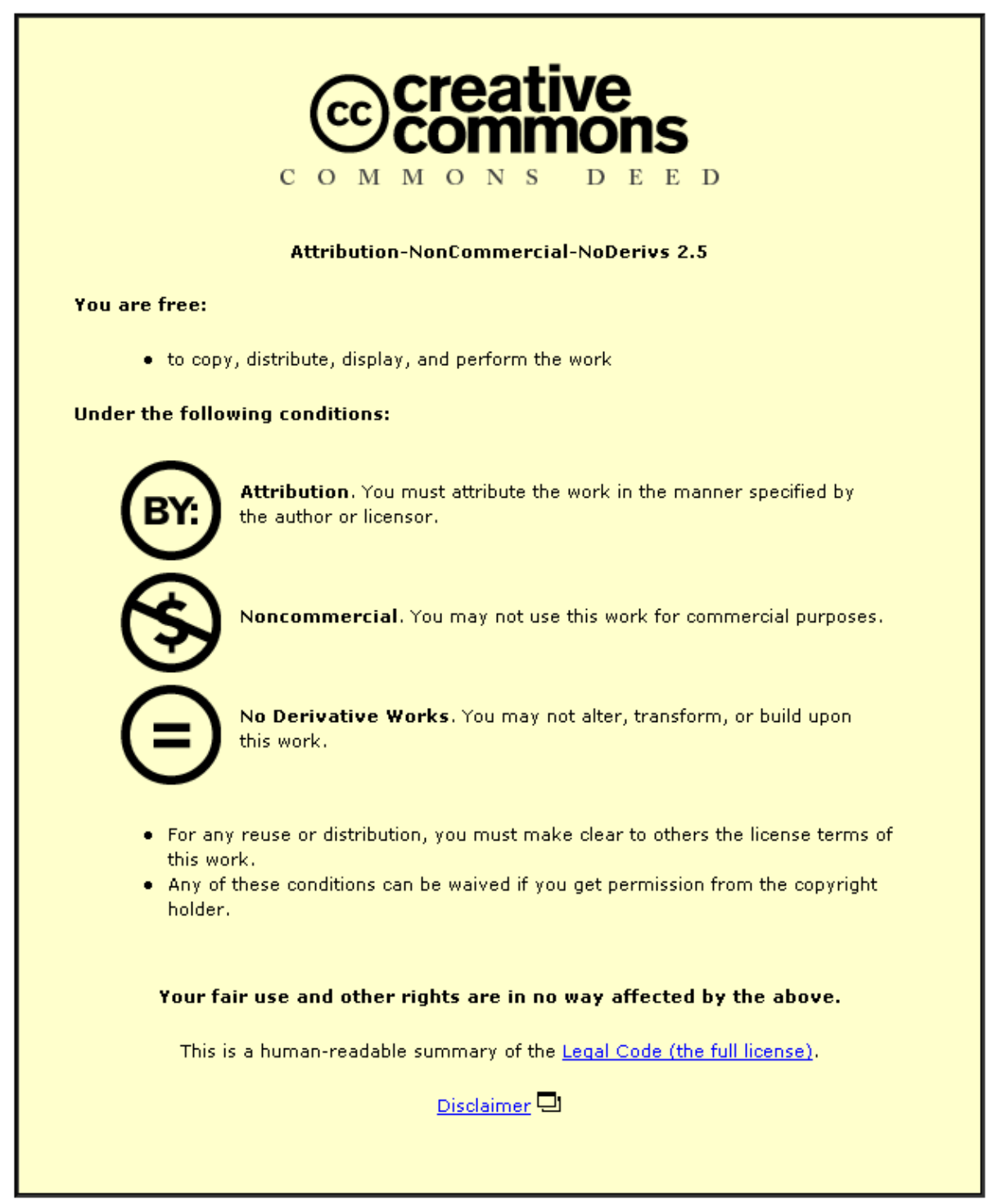

For the full text of this licence, please go to: http://creativecommons.org/licenses/by-nc-nd/2.5/ 
(Re)civilizing the Young Driver: Technization and Emotive Automobility KAREN LUMSDEN

Department of Social Sciences, Loughborough University, Loughborough, LE11 3TU, UK Email: k.lumsden@lboro.ac.uk 


\begin{abstract}
Historically, youths have presented challenges to the authorities via their appropriation of the automobile and related inversion of mainstream motoring values. Recently, this has been demonstrated in the contestation concerning boy racers in the United Kingdom and their engagement in deviant driving and car modification. Drawing on Elias' civilizing process ([1939] 1994) and work on technization (1995), this paper demonstrates how various measures targeted the emotive heart of this car-based community, thus attempting to (re)civilize young drivers. Data is presented from ethnographic research with boy racers and societal groups in the city of Aberdeen, Scotland.
\end{abstract}

Keywords: Automobility, car culture, boy racers, (de)civilizing process, technization, youths

\title{
Introduction: The (Auto)Mobility Turn
}

This paper adds to the mobility turn and studies of car cultures by focusing on a car-based community known as boy racers in the United Kingdom, their engagement in the practice of car modification, and authorities’ attempts to (re)civilize young drivers. The mobility turn in the social sciences has resulted in a plethora of studies on the automobile. John Urry (2007) argues that the study of mobilities such as the car should be central to sociological analysis since they lie at the heart of social life. Mobility has been built into the infrastructure of cities, including the 'momentary immobilities' of ports and freight depots, parking spaces and garages, airports and subway stations (Sheller and Urry 2006, 2). These emergent practices of physical, informational and communicational mobility are continually 'reconfiguring patterns of movement, co-presences, social exclusion and security across many urban contexts’ (Sheller and Urry 2006, 2). Automobility is just one type of mobilities system which shapes both space and sociality. It is not the car which is key but the system of 'fluid 
interconnections' created by automobility (Urry 2004, 26). Subsequent scholarly work ${ }^{1}$ has emerged which focuses on various aspects of automobility such as the experience of driving (Lupton 1999; Dant 2004; Thrift 2004; Laurier et al., 2008), gendered, classed and/or racialized mobilities (Scharff 1991; Wajcman 1991; Gilroy 2001), the car and national identities (Edensor 2004; Koshar 2004), the relationship between automobility and space (Taylor 2003; Merriman 2004), the ‘dark side’ of automobility (Urry 2004; Bergmann and Sager 2008), and solutions for a post-car future (Dennis and Urry 2009). Moreover, in recent decades societies have promoted a 'new level of individualized and intensified daily transport - a hyperautomobility' (Freund and Martin 2007, 37). This involves the social organization of space characterized by geographically expansive urban sprawl (which is a particular feature of the United States); hence fragmenting different spheres of life such as the family home, shopping malls, and work or educational establishments. This spatial arrangement necessitates use of the automobile as a mode of transportation while negatively impacting on community life via social exclusion for those whose do not drive and health problems related to vehicular emissions, accidents, and decreased physical activity (Freund and Martin 2007).

The automobile 'expresses and facilitates aspects of western culture based on individualism and getting ahead as an aggressive means of achieving at the expense of others' (Redshaw 2007, 121-22). Risky and deviant driving behaviours are not merely a consequence of the individual, but of the underlying representation and promotion of car culture through ‘dominant articulations’ of motor sports and driving practices in popular culture and advertisements (Redshaw 2007). These invoke notions of freedom in terms of 'excitement, adrenaline and social mobility... as if there were no restrictions, such as the need for fuel and the realities of traffic’ (Redshaw and Nicoll 2010, 415). They have also shaped forms of selfcontrol, specifically in relation to masculinity (Redshaw 2007). Cars are produced either as masculine: 'figured as rocket, bullet, or gun, that is as a sexual extension of the male', or as: 
‘Woman... as flashy possession, mistress or wife’ (Wernick 1991, 74). Through this: 'Prevailing patriarchal constructions of masculinity as dominance (where the car simply becomes an extension of the man) and femininity as submission ("she handles really well”) are reinforced' (Paterson 2007, 47). Cars are marked as a 'pleasure to drive', a pleasure which focuses on 'engine power, speed and driveability', despite the fact that urban streets are increasingly gridlocked, highlighting the immobility of automobility (Hagman 2010, 25, 2006).

For Mimi Sheller (2004, 225), the psychological investment in the car can be said to arise out of 'the sensibility of an entire car culture; the invested subject is moved (and thus brought to feel specific forms of agency) in particular ways'. Hence, 'automotive emotions' (Sheller 2004) are central to understanding the persistence of car-based cultures. Individuals have emotional investments in relationships between the car, the self, friends and family. The view that automotive technology insulates drivers from the outside world has been accused of oversimplifying the embodied experiences of driving and for neglecting the 'historicity and spatiality of these relational assemblages’ (Merriman 2004, 157-58). As Dant and Martin $(1999,11)$ argue: 'Different types of activity involve different groups of people who are in different places; cars extend sociality precisely by allowing us to organize the continuity between these different loci of sociality'. Ferguson's (2009) study of the car and social care illustrates how it can operate as a 'therapeutic space' and a 'mobile office' where casework goes on. Hence, in social work, the car is conceptualized as 'a "fluid container" for the processing of personal troubles, emotion and key life changes, which, when used skilfully, assists vulnerable people in making healing journeys' (Ferguson 2009, 277). In Car Cultures, Daniel Miller (2001) is critical of the social sciences for having ignored the fact that the car may be a different cultural form or experience among different groups. Cars are meaningful for certain car-based communities, which organize their ethos and rituals around this totemic 
material object. These groups tend to appropriate the car in ways that directly challenge or invert the norms of mainstream car culture.

This paper is concerned with a car-based community in the city of Aberdeen, Scotland who are commonly referred to as boy racers. In the United Kingdom, public concern from the 1990s onwards has centred on this particular car culture due to members' engagement in speeding, street racing, deviant driving manoeuvres (such as 'wheel-spins', 'doughnuts', 'handbrake turns', 'revving engines') and car modification. Boy racers have frequented Aberdeen's Beach Boulevard road since its construction in the late 1960s and are locally referred to as the Bouley Bashers. As a result of urban regeneration in this part of the city from the 1990s onwards, drivers became the focus of a host of measures aimed at cleansing urban space. Measures included redesigning the road layout (thus making it more difficult to partake in racing), CCTV cameras, community meetings, police patrols and specialized operations, a proposal to close the Beach Boulevard road in the evenings, the use of antisocial behaviour powers such as 'seizure of vehicles' and 'dispersal orders', and the related use of 'techno-fixes' such as noise meters and light emitters to regulate stereo systems and loud car exhausts, and window tints. Wells (2008) notes that traffic regulation and policing now incorporate a more scientific, evidence-based means of evaluating discretions, referred to as 'techno-fixes'. Typical examples include speed cameras, police radar guns, bus lane cameras and automatic number plate recognition (ANPR). The measures adopted by the authorities in response to boy racers aimed to reach the emotive heart of the car culture by tackling their engagement in car modification, risky or deviant driving behaviours and antisocial behaviour.

The discussion focuses on drivers' participation in car modification and the measures used to regulate this. The emotive aspects of the car culture expressed via modification were viewed by authorities as evidence of de-civilizing trends (Elias [1939] 1994) in relation to the 
car and the individual who modified/owned/drove it. This resulted in counter-attempts to (re)civilize driver behaviour and encourage self-regulation. The first part of the paper provides an overview of literature on car cultures and car modification. It then outlines Elias' ([1939] 1994) civilizing process and his essay on technization (1995). The remainder of the paper is concerned with the case study of boy racers in Aberdeen, Scotland.

\section{Car Cultures and Car Modification}

For Miller (2001, 2), the term 'car cultures' evokes 'the diverse, unexpected, sometimes tragic, contradictory humanity of cars; the taken-for-granted mundane that hides the extraordinary found in this material expression of cultural life'. Car cultures which have previously been the focus of social scientific investigation include the kortelliralli street racers of Helsinki (Vaaranen and Wieloch 2002), raggare (greasers) in Sweden (O’Dell 2001), Chicano Lowriders in the United States (Allard-Holtz 1975; Bright 1998) and the adolescent 'car cruising' scene in California (Best 2006). Boy racers have been an area of scrutiny in the United Kingdom, New Zealand, and Australia with scholars highlighting the link between working-class masculinity and participation in the scene (see Dawes 2002; Bengry-Howell and Griffin 2007; Falconer and Kingham 2007; Hatton 2007; Lumsden forthcoming). These car cultures also have in common participants' engagement in the practice of car modification, which is an integral element of many forms of car culture (Graham and White 2007). Since the invention of the car, myriad grass roots car cultures have existed and evolved in tandem with the mainstream motoring industries. As Franz (2005) argues, car customization allowed the first motorists to redesign the car and renegotiate their cultural identities and their relationships to public space in terms of gender and technical expertise. Within the United States, car modification has its roots in the early days of automobility and has continued among several subcultures following World War II, such 
as hot rodders, drag racers and stock car racers (Franz 2005). Moorhouse (1991) argues that the illegal street racing scene in the United States will continue to have an effect on the increasingly organized and official world of hot rodding and, although it has never been regulated, street racing is a sport which will never die. Many of the subversive automotive differences pioneered by hot-rodders were incorporated into the models of the mainstream car manufacturers (Gartman 2004, 190). Hence, these subcultures can become 'just another source of individuality and difference for the more pluralized and levelled automotive market’' (Gartman 2004, 190).

O’Dell's (2001) study of raggare in Sweden shows how cultural groups can (re)appropriate consumer goods such as the car. In this case, it was the vulgarity of the 1950s American car (from a middle-class perspective), which gave it a new life in the hands of working-class males. These cars became a forum for self-expression and the raggare developed their own aesthetic code which was partially a reaction to the dominant and normative Swedish preference for the practical and rational. In their work on boy racers in England and Wales, Bengry-Howell and Griffin $(2007,453)$ claim that cars operate as 'tools of identity making', which symbolize key aspects of identity and carry meanings of personal significance. For boy racers, the process of doing the modifications was discussed in terms of the physical labour invested in 'a whole range of alterations that serve to personalise a car and make it truly theirs’ (Bengry-Howell and Griffin 2007, 447).

Hence, via their (deviant) appropriations of the automobile, these groups challenge the authorities and the related governance and policing of public highways. More often than not, public concern or 'moral panics' centre on youthful driving practices and the risks these pose to the majority of 'respectable' motorists (Lumsden 2009). However, the car aids youths' traversal of the perilous path to adulthood. The mobility it affords its users extends to 
include the psychological, emotional, and interactional experiences encountered by youths in their forging of car communities.

\section{The Civilizing Process and Technization: The Case of the Automobile}

Despite the fact that Norbert Elias paid particular attention to the automobile in his seminal work The Civilizing Process ([1939] 1994) and his essay on 'Technization and Civilization' (1995), sociology has generally failed to acknowledge the merit of his framework for the study of contemporary automobility (with the exception of Tim Dant [2006] whose work will be discussed in due course). According to Elias (1995, 9), the relationship between the progressive reductions in accidental deaths by driving in western nations can be related to the civilizing process: 'the acquired self-regulation that is imperative of a human being'. Elias $(1995,8)$ conceives of this as ‘an involuntary learning process for humanity’, which can be traced back to the earliest days of humankind and also has no end point. His work on the civilizing process is concerned with the processes of self-constraint and social constraint in relation to expressions of violence, development of the feelings of shame and repugnance, and development of manners and etiquette (such as table manners and the control of bodily functions). For Elias, civilizing processes also have de-civilizing counterpoints. Thus, although civilizing processes have largely been dominant in the history of humankind, at any given time they can balance each other out, or one can become more dominant (Mennell 1990). Moreover, 'civilizing and de-civilizing changes in a society can follow each other in varied sequence' (Elias 1995, 9).

In the Civilizing Process ([1939] 1994), Elias uses the example of the automobile to demonstrate how the social constraint towards self-constraint has changed and increased since medieval times (Mennell 1995). For Dant (2006, 295-96), it is this 'use of the development of roadways and traffic as a metaphor to explain the civilizing process that most 
readily evokes the interconnections of materiality and civilization'. In the 'muddy roads of a simple warrior society' there is little traffic and hence a low risk of collision with other travellers (Mennell 1995, 2). However, in modern society individuals have to deal with a mass of traffic in built-up cities which is externally controlled via an interconnected and complex system involving traffic lights, signals and signs, and various policing and surveillance tools such as speed cameras ('techno-fixes') and so on. Crucially, Elias sees this external control as being founded on the assumption that individuals will undergo a form of self-regulation in line with both formal and informal traffic rules:

Constant vigilance, foresight and self-control are needed, whether a person is driving or on foot. The chief danger people pose to each other is through loss of self-control. An error of judgement in foreseeing some movement can kill. Even greater danger, though, comes from the frustrations of the traffic leading someone to lose control, vent his or her aggression on another driver, or in any way ‘do something stupid’. (Mennell 1995, 2)

Elias revisits his work on the automobile in his essay 'Technization and Civilization' (1995). He draws on official statistics of road accidents from various countries in order to illustrate and test his theory of the connection between the two long-term processes of technization and civilization (Mennell 1995). Elias (1995, 7) defines technization as 'the process through which, as it progresses, people learn to exploit lifeless materials to an increasingly greater extent for the use of humankind, by treating and processing them, in war and peace, mostly in the expectation of a better life.' He does not restrict technization to the period following the industrial revolution, but instead argues that it must be conceived of as a process involving humankind which developed slowly at first, since individuals had relatively little knowledge 
of the world they resided in, but then accelerated in tandem with the growth in knowledge of 'lifeless nature' (Elias 1995, 8). In the former instance, he uses the example of the harnessing of fire which 'raised the returns for work, reduced the toil and thus offered the chance of a better life... It also improved the means of warfare...' (Elias 1995, 8).

For Elias, technization such as the harnessing of fire and the introduction of the automobile brings a new de-civilizing dimension to social life, which members of society have to learn to live with. Here, we return to his point regarding the civilizing process and self-regulation, with motorists learning how to drive and how to interact with other road users. Self-regulation on the part of everyday drivers is key to counteracting the de-civilizing effects of the automobile. Society responds to the de-civilizing effects of new technology by introducing laws to regulate it. For Elias (1995), the decline in road deaths with the development of the civilizing process is therefore not only linked to technical improvements, but is related to the way in which drivers cooperate on the roads in line with the driving behaviours of other motorists and the movement of other city dwellers (Dant and Martin 1999). The consequences of drivers not adhering to formal or informal rules of the road are evident in instances such as road rage. For instance, as Katz $(1999,35)$ notes, the rage experienced by motorists in incidents such as being 'cut off' by other motorists is systematically linked to certain patterns of spatial interrelationships:

When traffic flows smoothly, if a rude driver cuts in close, one must fall out of the flow by hitting the brake or at least lifting off from the accelerator, in the process physically pulling oneself out of a previously tacit intertwining of body and machine. 
Self-control requires individuals to shape who they are in relation to the car and the desires connected to it, while also addressing the limits and dangers of the car (Redshaw 2007). For Dant (2006, 297), this self-regulation goes further to include not just the acceptance of standards of driver behaviour, but also drivers developing an 'embodied relationship with their vehicles'. He extends Elias' work by considering not just the materiality of things, but also their morality. For instance, individuals are often seen as responsible for the actions relating to particular objects such as cars or guns (Dant 2006), which are viewed as dangerous or lethal weapons in the wrong hands, particularly in the former case when in the hands of youths or novice drivers.

Moreover, Dant (2006, 297-98, original emphasis) warns us to be cautious of Elias’ argument that the trajectory of civilization is an unplanned process since:

...clearly those who exercise power on behalf of a community do plan the design and introduction of such devices as speed bumps and cameras. The cultural response that attempts to reduce the violent consequences for others within the society of individual desires, involves a lengthening of the chains of interdependence between people. This happens not only through selfregulation because constraints remain external as legal sanctions (the speeding fine) and material forms (the speed bump).

For example, Merriman (2006, 76) argues that ‘different architectures, knowledges, instruments and legal frameworks may be seen to function as "technologies of government" which translate political rationalities and shape the performances and movements of drivers, vehicles, and the spaces of the road...' Various interested (expert) groups thus become involved in 'ongoing, partial, and contingent attempts to assemble and govern driving- 
subjects through and in relation to their bodies, vehicles, and other spaces, texts and thoughts - as travellers, consumers, criminals, statistics and participants in scientific experiments' (Merriman 2006, 76). Publications such as The Motorway Code and the Highway Code function as 'technologies of government' that can be 'devised, promoted, and circulated in an attempt to govern the performances of vehicle - drivers coaxing drivers to govern the movements and conduct of themselves and their vehicles in particular ways...' (Merriman 2005, 243). Thus, as Packer (2008) notes in his analysis of American automobility, different populations' access to and use of automobility has historically been organized and regulated through a nexus of power/knowledge relationships.

As was the case with the societal reaction to Aberdeen's boy racers, governments and authorities do knowingly and deliberately adopt various strategies and measures in order to curtail deviant driving behaviours, as do members of communities and citizens more generally. It will be shown that the increasing social constraint and thus attempts to foster self-constraint in young drivers were indeed part of a planned process in relation to the decivilizing effects of the car. Recent attempts to respond to the de-civilizing effects of the car when in the hands of youths, and also more specifically in relation to the practice of car modification (which inverts and challenges mainstream car culture and the legitimate use of technology-ies), can thus be conceived of as means through which to (re)civilize young drivers.

\section{Methods}

The discussion is supported by data gathered through ethnographic research with the boy racer culture in the city of Aberdeen, Scotland as part of a doctoral study. Data was collected between September 2006 and August 2007. Semi-structured and ethnographic interviews were also conducted with drivers during the course of the fieldwork. Access was aided by 
Grampian Police who regularly met with a group of drivers from the beach area of the city. These 'Drivers’ Group’ meetings took place every few months and it was here that I met the two gatekeepers: Debbie and Robert. ${ }^{2}$ The main location for the research was Aberdeen’s seafront or as it is otherwise referred to, the Beach Boulevard. [Picture 1: Aberdeen's Beach Boulevard in 2008. Photograph by author]. In total, around 150 hours were spent in the field. I also accompanied drivers to car shows and events across Scotland (referred to as 'meets' or 'cruises') and to local garages, scrap yards and car accessory stores. Internet sites which were created and utilized by informants were a further source of data.

In order to analyse the societal reaction, semi-structured interviews were conducted with members of the outside groups. This included police officers, a local councillor, Member of Parliament, Member of the Scottish Parliament, three journalists, two council officials, two residents, and a group interview with four residents present. Content analysis was employed regarding media reports which focused on the culture. Over 200 articles were collected between August 2003 and September 2008 from daily local newspapers: the Press \& Journal and the Evening Express; and two free newspapers distributed weekly across Aberdeen: The Independent and The Citizen. Relevant articles from national media outlets such as BBC News online, The Times, The Guardian, and The Scotsman were also analyzed. Modifying (or 'modding', as it was referred to by the drivers) played an important role in the subculture. When I first joined the group to conduct fieldwork Debbie told me not to worry that my car was not modified. Robert reiterated this. However, during the course of the fieldwork it became clear that 'modding' was important in order to belong to the group and Robert, in particular, made numerous attempts to involve me in the practice. This was one means by which participants attempted to include me in their activities and could be viewed as evidence of my acceptance in the field. For instance, during evenings at Aberdeen's seafront, Robert pointed out passing cars which he believed were good examples 
of what I should aim for when modifying my car. Steven, who also owned a Fiat Punto, attempted to sell me parts from his old Punto, which included a body kit and Fiat Sporting alloys. On one occasion he offered to sell me his tyres and alloys for $£ 80$. After hearing this, Robert advised me: 'he’s just being greedy. Like I said, you could get them all for $£ 60$. Try to haggle if you want to’.

\section{Car Modification and (Re)civilizing the Young Motorist}

'Modding'

Before focusing on the authorities' regulation of 'modding', it is important to contextualize the discussion by outlining the youths' involvement in the practice and its significance for individual and group identity. The process of 'modding' involves taking a standard car and altering its physical appearance (including the interior and exterior) as well as its performance. ${ }^{3}$ Typical exterior modifications include tyres and alloys, lowering the suspension, bigger and louder exhausts, tinted windows, smoked-out lights, body kits, bumpers, spoilers, bonnet vents, and under-car neon lights. Interior modifications include sports seats and in-car entertainment (ICE) such as stereos, sub-woofers, speakers, amplifiers, DVD players, games consoles or computers. As Graves-Brown (2000) notes, the car is a 'personal mobile space', which is made more homely through the inclusion of sound, communication and entertainment technology (Urry 2000). 'Modding' allows the owner to express him or herself through the car. For instance, during a discussion about car modification, Brad acknowledged the visual impact of a modified car:

I modified the [Renault] Clio for more of an experiment than anything else. When I bought it, it looked really shitty. So I did as many modifications as I could to it. People would take note when I was down the beach and I got lots 
of admiration for the work I'd put into it. It definitely made heads turn once it was finished but eventually the novelty wore off. So I sold it and bought the Ford Fiesta. (Fieldnotes, July 2005)

As Bright $(1998,596)$ writes: 'Customizing a car enlarges the possibilities of bodily inscription, exhibition, and... social relations. These activities take place on cars that are in reality mobile canvases'. The car modifiers creatively established their presence, identity and meaning through expressions, signs, and symbols related to the car. 'Modding' was crucial for the creation and maintenance of individual and group identity. When asked: 'Why is your car important to you?' Debbie likened modification to any other legitimate hobby or leisure pursuit:

I could answer that by asking, ‘well why is granny’s knitting important to her, or your mum's bingo, or meeting for a cup of tea?' It's important because it's a hobby. It's a love for cars and engines and most people have grown up with this in their blood, watching their dads or uncles working on cars and so they have an interest in it. That's also why I wouldn't be stupid and risk losing my license or totalling my car by driving like an idiot. I’ve put so much time and money into it I don't want to wreck it and I need it for everyday. Losing my licence would change my entire life. (Interview with Debbie, October 2007)

Her interest in cars is traced back to her childhood and an influence from male members of her family. The mobility the car affords its user is also remarked upon by Debbie, who would not risk losing her licence or 'totalling’ (crashing) her car. For Robert, the car plays a symbolic and practical function in his life, by allowing him to travel to work each day. When asked why his car is important to him, Robert replied: 'it gets you to work but by modifying 
it the car happens to look good when whizzing past folk on the A90. ${ }^{4}$ So it's that and the practicality of it'. Bengry-Howell (2005) claims that for many modifiers the car serves as an object of self-extension, which extends what the human body can do and what it can mean. 'Modding' involved turning a mass-produced factory good into something unique, individual and 'your own'. Participants claimed that their cars were modified to reflect their personal tastes:

Interviewer: Why do you think people enjoy modifying their cars?

Debbie: $\quad$ It's because they're interested in cars and they want to make theirs look different from everyone else. My car is different from other Ibizas - it's individual. It's how I want it to look and there's a reward when you do all the work yourself and invest lots of time and money in it. And nowadays a car is the next most expensive item after a house and lots of people own a car before a house. It's the first thing that most people buy which costs more than $£ 200$. (Interview with Debbie, October 2007)

Debbie comments on the importance of modifying a car to make it look different from other mass-produced cars, in this case, other Seat Ibizas, and to do so in a way which reflects her own personal taste. She also highlights the importance of modifying the car herself. The time, effort and money put into modifying a particular vehicle make the experience worthwhile and rewarding. Robert also believes that modifying a car makes it ‘your own': 
Robert: It makes the car your own. It's individual. You're taking a factory product and doing what you want to do. It's about style and expression, individuality.

Interviewer: But at the end of the day is it not still a Fiat?

Robert: $\quad$ But it's trying to make it your own Fiat and trying to inject something into the brand. (Interview with Robert, October 2007)

Paul pointed to the importance of individuals modifying their cars for changes in the car industry to take place: ‘without us, people wouldn’t have massive alloys as standard on their car, or cars that have as much horsepower'. For Paul, grass-roots car modifications influenced the design of manufactured cars. He remarked: ‘my gran wouldn’t have alloys as big as she does on her Jag if it hadn’t been for people like us'. He also recalled a rumour concerning one of the car modifiers at Aberdeen Beach who started a small company and sold it to Halfords ${ }^{5}$ : 'this proves that we're not all just idiots who race and drive dangerously. We actually spend a lot of time and money on our vehicles'. This is reminiscent of Gartman’s (2004) point that subversive automotive differences can be incorporated into the models of the mainstream car manufacturers. Hebdige (1979) argues that dominant culture is able to absorb the subversive image of a subculture and thus sustain the impact of the 'anarchic imagination' of the youths via both the conversion of subcultural signs into mass-produced objects and the labelling and re-definition of deviant behaviour by dominant groups such as the police and media. However, via 'modding' the youths also seek to imitate the design of higher-priced sports cars that are economically out of reach. As the car industry progresses with new designs and technologies, so do the car modifiers (and vice-versa). 
Members of the group often grew bored of their cars after they had been modified. As Brad recalled with his Renault Clio: 'eventually the novelty wore off'. After they had carried out countless modifications and received admiration and respect from other members of the culture they would sell their car and buy another to modify. The amount of time, effort and money invested in the car results in it being seen by the modifiers as a practical and symbolic extension of the self: 'a second skin which not only symbolizes the self but transforms it' (Graves-Brown 2000, 158). This is only so until such a time that the individual grows out of the particular car, hence discarding it and moving onto their next project. As Dant (2006, 299) writes: “The material capital of my car "wears out” not simply through the car's engineering wearing out but through its style becoming unfashionable or its comfort or capacity inappropriate to my changing lifestyle or body’.

The drivers did not admire individuals who bought new cars built by manufacturers to reflect the modification scene or those whose parents had financed the purchase. Drivers who ‘cruised’ the Beach Boulevard in sports cars such as Ferraris or Porsches were referred to as 'mummy's' or 'daddy's boys'. They also linked those drivers who crashed their cars, to those who were driving a car owned or bought for them by a parent. Debbie described an occasion when a boy driving a Porsche 'totalled' the car at the top of the Boulevard by driving onto the roundabout: ‘you don't get a lot of boys coming down with daddy's car because that's what happens. They show off, crash, and then you don't see them again'.

These examples demonstrate the way in which the modified car, as a symbol within the subculture 'is built up out of personal identities and narratives, in conversational rituals marking the ties between the conversationalists and the symbolic objects they are talking about' (Collins 2004, 87). The owner's knowledge of the car also establishes a social relationship with it and a context that will shape subsequent physical interaction with it (Dant and Martin 1999). 


\section{Regulating Car Modification}

Rituals such as car modification mark boundaries of inclusion and exclusion and thus can be contested by individuals in various relationships to those boundaries (Collins 2004). For the local community and authorities, the youths’ occupation of the Beach Boulevard was problematic. The exhibitionist nature of the culture at Aberdeen's seafront was referred to on numerous occasions by concerned residents, police and council officials - one of whom described the Beach Boulevard as a 'mechanical catwalk of souped-up cars'. Via their appropriation of the car, the racers were seen to challenge normative, mainstream car culture. The modifications carried out to their cars were the subject of scrutiny from outside groups such as the police and local authority. Youths were viewed as lacking the knowledge and expertise necessary in order to safely modify a car:

The stuff that goes on there now it's more what we call the construction and use regulations. How they personalize their cars. They add lights onto them, they add different exhausts, they do stuff to the engines - tune the engines. They can do it without the full understanding of the law. (Interview with

Officer 1, Roads Policing, October 2006)

The personalization of the car and emotive aspects of 'modding' are viewed as problematic by this officer. Thus, the technology of the car is de-civilized in the hands of youths. By 'modding' the car, the youths are altering the factory specifications, which has consequences for road safety. An officer comments on the dangers of car modification: 
If I see a Vauxhall Corsa or one of these cars with dropped suspension, tinted windows, there's a fair chance that the driver's seat is going to be lowered down. The girlfriend... her seat belt was on but because the seat was angled so far back, the car flew through the air and landed. She... went out underneath the seat belt. [The driver] got five years in jail. He'd lowered the suspension and cars are designed by the manufacturers to be driven in a certain way. When the research and development are done it's the height from the axle to the chassis and all these things are minutely looked at to make sure what they've got as a package is safe and it undergoes testing. When these kids get these cars they think, 'nah, nah, nah. Citroën have spent millions of pounds on development. I'm going to put different suspension springs in them, different set of dampers on it, lowered suspension, bigger wheels on it' and then they wonder why the cars don't handle. (Interview with Officer 2, Roads Policing, October 2006)

The officer's comment relates to Dant's (2006) point about the morality of material objects. The car must be treated with respect and due diligence, in line with the expert knowledge of the motoring industry. In the wrong hands, the car is deadly.

\section{'Seizure of Vehicles': 'Crush it into a Cube'}

As a result of community concern with regards to boy racers, the authorities made use of powers introduced in 2004 under the Antisocial Behaviour etc. (Scotland) Act. These powers have been used across the United Kingdom (and in England and Wales are incorporated in the Antisocial Behaviour Act 2003) in order to tackle anti-social automobility and, more generally, a wide range of behaviours defined as ‘anti-social'. In the case of Aberdeen’s boy 
racers, this included the use of 'dispersal orders', which were implemented on three consecutive occasions in the beach area of the city in summer of 2005 (and involved police dispersing groups of three or more drivers from the area for up to 24 hours), and also 'seizure of vehicles'. 'Seizure of vehicles' (which will be focused on herein) restricts both the mobility the car affords its user and the emotive aspects of the car expressed via 'modding' and/or deviant driving. With the former, this was evident via the removal of the car from the driver if they did not heed the first warning that they were given by police. This would occur whether they were the owner of the car or not. It also tackled the emotive heart of automobility by threatening the destruction of the car via the act of crushing if it went unclaimed after having being seized, and/or the motorist refused to pay the required fine for recovery of the vehicle. Once a car had been seized and impounded by the police, in order to retrieve the vehicle the owner was required to pay a fine of $£ 105$ to cover removal of the vehicle and an additional $£ 12$ for each 24 hour period that the vehicle was held by the Retaining Authority. The Retaining Authority could dispose of the vehicle if it had not been claimed after a period of three months (Scottish Executive 2006). ${ }^{6}$ A police officer believed that anti-social behaviour legislation was effective in dealing with deviant driving:

The vast majority of offences now are dealt with by use of the anti-social behaviour [legislation]... I mean, I don’t know, they may see it differently but from my point of view I think it has a much better effect than just giving out tickets. (Interview with Officer 1, Roads Policing, October 2006)

'Seizure of vehicles' helped officers to address illegal modifications and anti-social use of the car: 
If I go down and they're playing loud music or they're revving their engine or if they're sitting at lights, skirl the wheels, and take off at the lights, then I stop them. They're given an official warning under the terms of the anti-social behaviour legislation. The warning is then recorded on a national computer. They’re also sent out a letter by the Antisocial Behaviour Unit saying: ‘you’ve been warned. If you get another warning, i.e. if you're stopped again we'll seizure your vehicle'... It's a different way of thinking rather than just reporting it to the [Procurator] Fiscal. ${ }^{7}$ It takes months to report something and the Fiscal might not take any proceedings at the end of the day. (Interview with Officer 4, Antisocial Behaviour Unit, August 2006)

The immediate removal of the car was seen to curtail the drivers' mobility and also teach them a lesson in terms of the consequences of not regulating their behaviour. For officials at Aberdeen City Council, the powers were successful in tackling anti-social behaviour and responding to the concerns of the community:

The use of the dispersal was effective. It was very quick in bringing down the level of complaints and the feedback from residents was good as well. But obviously it’s really resource intensive for the police and it was really a victim of its own success because we'd dropped the complaints down so much you can't continue to use it even if you wanted to. (Interview with Aberdeen City Council Officials, May 2007)

A second council official described 'seizure of vehicles' as a 'problem for people where it hurts', which demonstrates the way in which the legislation is geared at tackling the heart of 
the car culture itself and the 'dominant articulations' of motor sports, racing and car advertising (Redshaw 2007). The measures adopted by authorities such as 'seizure of vehicles' target the 'destructive potential’ (Redshaw 2007, 122) of the culture.

\section{The 'Techno-Fix'}

In line with anti-social behaviour powers, various 'techno-fixes’ (Wells 2008; Lumsden 2012) such as noise meters and light emitters were used by council officials and/or police officers to regulate the way in which the drivers modified their cars. For instance, modifications such as window tints or lights which did not adhere to road traffic legislation were the focus of police attention:

There's a thing with the tint on windows. Now, you're only allowed a 30 per cent tint or you have to allow 70 per cent of light in. You see some of the cars...the windows are completely blacked-out. Now we have tools, we have equipment that can measure the amount of light that's emitted. (Interview with Officer 2, Roads Policing, October 2006)

As Atkinson $(2007,1909)$ points out: 'the local state... has increasingly pursued socio-legal strategies to control anti-social behaviour generated by social nuisances...' and music from cars 'create[s] an increasingly constant and contested presence challenging notions of public use and access'. An official from the local authority’s Antisocial Behaviour Unit highlighted the use of anti-social behaviour powers in relation to noisy car exhausts:

There's a bit of a grey area around the exhaust noise levels and the police are lobbying to get a common agreement across Scotland as to what the 
measurement should be because just now they haven’t really been effective and we could be dealing with people with excessively loud exhausts... The police [in Tayside] have a brush handle and they basically stick it up the exhaust pipe to test the baffle that's there. I think I'm right in saying that if the baffle is not there than that's some sort of offence. (Interview with Aberdeen City Council Officials, May 2007)

For the youths, the use of these measures proved problematic as they lacked awareness of the laws in relation to noise pollution and more generally what was legally acceptable when 'modding' a vehicle. At a 'Drivers’ Group’ meeting they voiced concern regarding the application of the legislation:

Paul told [the officer] the way the legislation was being used was unfair. He was stopped and fined but someone else he knew was fined more and given points on his licence. The officer told him the reason for this is the level of tint and whether or not it is determined to be dangerous for driving... Debbie said she was stopped for having a noisy exhaust. The first reading they took with the meter was over 100 decibels but then the second was 90 -something so she was ok. (Fieldnotes, ‘Drivers’ Group’, December 2006)

Moreover, as a result of 'Drivers' Group' meetings, information was posted on a subcultural website to inform drivers of the consequences of misbehaving:

There has been a lot of coverage lately regarding the police cracking down on anti-social behaviour etc. around the beach area, in particular with drivers that 
frequently flout the laws in the area. The police mean serious business with these crack downs. Not only are they randomly stopping people with good reason, but they have one of the cameras watching the Boulevard at all times. Last night I was parked next to a friend when a police car came up onto the trammers $^{8}$ and asked if they could have a word. They informed him that he had been seen driving at speed on the Boulevard on a number of occasions earlier that night and basically gave him a talking to regarding the possible action they could take against him. So, be warned. Even when there are no police in sight they are watching. But at the same time if you are doing nothing wrong and your car is legal then you have no worries. (Fieldnotes, April 2007)

Within the culture, a more informal means of policing was evident where the core of the group (who attended 'Drivers’ Group’ meetings), conveyed the measures and expectations of the authorities to the rest of the drivers. The drivers are reminded of the authorities' surveillance of the area via CCTV and of the importance of exerting self-control over their driving in order not to bring the culture into disrepute.

\section{Conclusion}

The practice of 'modding' allowed young drivers to express themselves through the material object of the car. As Bright $(1998,596)$ notes, cars can be conceived of as 'mobile canvases'. The car modifiers creatively established their presence, identity and meaning through expressions, signs and symbols related to the car. The car allowed them to create and sustain individual and collective identity. The modified car extended the mobility of the body and was symbolic of its owner through the personal modifications carried out. Hence, the 
examples cited demonstrate the (auto)‘emotive emotions’ (Sheller 2004), which are embedded in the car and expressed via rituals such as 'modding'. The young drivers attempted to stamp their own mark on the technology of the car by engaging in aesthetic, technical and/or mechanical modifications. An individual with an investment in driving or an attachment to a particular car culture will also be able to 'read vehicles and driving in such a way as to recognize another's position and disposition, but others who are marginal or strangers to the relevant segment of the practice will remain oblivious to the intended meaning’ (Warde 2005, 145).

However, rituals such as car modification mark boundaries of inclusion and exclusion and can be contested by individuals in various relationships to those boundaries (Collins 2004). For the local community and authorities, the youths' occupation of the Beach Boulevard was problematic. Via their (deviant) appropriation of the car, boy racers challenged and inverted mainstream motoring norms. As evidenced through societal contestation and periodic 'moral panics' concerning their behaviour (Lumsden 2009), boy racers were indicative of wider de-civilizing processes in relation to the automobile. By engaging in 'modding' with their own hands, they demonstrated a lack of self-regulation akin to that evidenced in deviant driving such as speeding and racing. As Elias $(1995,25)$ writes:

Controlling the car (including maintaining it) is nothing but an extension of the driver's self-control or self-regulation. This pattern of self-regulation by a driver at the wheel of his car however, is determined to a large extent by the social standard that society in every country has developed for the individual self-regulation of the men and women who drive cars. 
The youths in this study challenged and flaunted the societal standards concerning maintenance of the car by altering the standard factory setting. This was seen as problematic despite the fact that many members of the culture were (or were acquainted with) individuals who worked as car mechanics. It was also viewed as problematic in spite of the relationship noted between mainstream car manufacturers and niche subcultures such as boy racers. As Gartman (2004) points out, subversive automotive differences can be incorporated into the models of the mainstream car manufacturers. Despite this, 'modding' was seen to challenge expert knowledge concerning the car and thus provide challenges for road safety. Thus, as Packer $(2008,9)$ notes, safe and risky come to be characterized through group or demographic identity such as youth, which comes to be:

...described by experts and represented in the mass media as hopelessly dangerous. In these instances claims regarding the unsafe driving or attitudes of a group... and the unsafe form of automobility they employ... have largely been used to legitimate the monitoring, regulating, and minimizing of access to and use of the automobility system.

In the case of Aberdeen's boy racers, the government and authorities knowingly and deliberately adopted various strategies and measures in order to curtail deviant driving behaviours. This happens not only through self-regulation but also through constraints which remain external to the individual (Dant 2006). In this case, constraints included (amongst other things) road traffic legislation, anti-social behaviour legislation and 'techno-fixes'. The increasing social constraint and attempts to foster self-constraint in young drivers were part of a planned process in relation to the de-civilizing effects of the car. Means of regulating car use such as ‘techno-fixes’ (including noise meters and light emitters) and 'seizure of 
vehicles’ powers can be viewed as tactics through which to (re)civilize young drivers. The boy racers were viewed as having breached both formal road traffic legislation and the informal norms of the road via driving incivilities such as speeding, street racing, careless or risky driving manoeuvres more generally and 'modding'. Importantly, these measures attempted to address the emotive aspects of this car culture which were conveyed via the practice of 'modding'; in addition to threatening the mobility the car affords its user (via the threat of removal/destruction/crushing).

Attempts to police or regulate the emotive, performative and/or artistic aspects of car cultures are at odds with the message portrayed in mainstream culture via films, reality television exposés of high-speed police chases, car advertisements, celebrity culture and motor sports. They target the ‘driving pleasures’ integral to car advertisements (Hagman 2010) and challenge ‘dominant articulations’ of the car (Redshaw 2007). Furthermore, as Merriman (2006, 78-79) argues in relation to Britain’s Motorway Code, these measures can also be viewed as a 'series of technological and political devices' which are 'distributed with the intention of governing the performances, desires and experiences of drivers-in-vehicles; subtly changing the relations between the bodies of drivers, vehicles, and the spaces through which they travel...'

Authorities face a conundrum as to how to address the issue of road traffic fatalities, collisions, and anti-social forms of automobility, particularly given that achievement of nil or low numbers of road traffic collisions and/or fatalities is nigh impossible in the current system of automobility, related promotion of individuated and aggressive driving styles, and the possibility for 'human error' in everyday driving. As Dennis and Urry (2009) point out, roads can be conceived of as 'killing fields' of late modernity. Policing, governance and regulation shifts to addressing the expressive, emotive and psychological aspects of car ownership and driving behaviours which are deemed to be problematic and/or which lie 
outside the acceptable and respectable norms of automobility. This specifically occurs in the context of the inexperienced young driver who must be socialized and (re)civilized into mainstream 'normal' car culture. Hence: 'While the manufacturers of vehicles encourage the idea of the subject as both in control and potentially out of control, the wagging finger of authority is required to temper this force' (Redshaw and Nicoll 2010, 426). For youths, the use of these measures proved problematic as they lacked awareness of what was legally acceptable when 'modding' a vehicle. Moreover, this required them to keep up with developments in the use of 'techno-fixes', which imposed limits on certain modifications that had not previously been policed.

Interestingly, a more informal method of policing was also evident within the culture where the core of the group attempted to convey the expectations of the authorities to the rest of the drivers. Hence, participants were reminded of the importance of exerting self-control over their driving while in the Beach Boulevard vicinity in order not to bring the culture into disrepute. In the context of Elias’ ([1939] 1994) civilizing process, this further exemplifies the complex chains of interdependence which exist between individuals in both the planned and unplanned trajectories of civilization. This paper demonstrated the social aspects of the car which in the hands of certain individuals/groups became a highly valued and subversive cultural good. When in the hands of youths, this material object is conceived of by authorities and the respectable motorist as a lethal weapon, thus demonstrating the morality attached to the technology of the car (Dant 2006).

\section{Endnotes}

1. It is not possible within the context of this discussion to do justice to the myriad social scientific analyses which have focused on automobility and mobility more generally. Social historians have long focused on the automobile as an object of curiosity and scrutiny (see Flink [1970, 1975]; Foster [2003]; Ling [1990]; 
O’Connell [1998]; Rae [1971]). Moreover, French social theorists such as Lefebvre, Barthes, de Certeau and Baudrillard can be viewed as foundational figures in the study of automobility (Inglis 2004).

2. Pseudonyms have been used in order to protect participants’ identities.

3. Within the culture, cars were referred to as 'souped' or 'souped-up', which means they have been modified for higher performance.

4. The A90 is a major north to south road in eastern Scotland running from Edinburgh to Fraserburgh.

5. Halfords (founded in 1892 as a cycle shop) is Britain's leading retailer of automotive and cycling products. Its Autocentres provide car service, repair and MOTs to fleet and retail customers across Britain. In 2012 Halfords operated 467 stores across Britain.

6. Before they can dispose of a vehicle the Retaining Authority must have been unable to deliver a seizure notice, or if it was delivered, the owner must have failed to remove the vehicle.

7. In Scotland the Crown Office and Procurator Fiscal Service (COPFS) is responsible for the prosecution of crime, the investigation of sudden and suspicious deaths, and the investigation of complaints against the police. The Procurator Fiscal has the discretion not to prosecute and to pursue alternatives, but ultimately remains under the directions of the Crown Office and Lord Advocate.

8. The 'trammers' are an area at Aberdeen's seafront where remnants of the city’s old tramlines remain. Drivers use this space in the evenings to park their cars and socialize with one another.

\section{References}

Allard-Holtz, J. 1975. “The “Lowriders”: Portrait of an Urban Youth Subculture.” Youth \& Society 6 (4): 495-512.

Atkinson, R. 2007. “Ecology of Sound: The Sonic Order of Urban Space.” Urban Studies 44 (10): $1905-17$.

Bengry-Howell, A. 2005. Performative Motorcar Display: the Cultural Construction of Young Working Class Masculine Identities. PhD diss., University of Birmingham.

Bengry-Howell, A., and C. Griffin. 2007. “Self-made Motormen: The Material Construction of Working-class Masculine Identities through Car Modification.” Journal of Youth Studies 10 (4): 439-58. 
Bergmann, S., and T. Sager, eds. 2008. The Ethics of Mobilities: Rethinking Place, Exclusion, Freedom and Environment. Aldershot: Ashgate.

Best, A.L. 2006. Fast Cars, Cool Rides: The Accelerating World of Youth and their Cars. London: New York University Press.

Bright, B. 1998. ““"Heart Like a Car”: Hispano/Chicano Culture in Northern New Mexico.” American Ethnologist 25 (4): 583-609.

Collins, R. 2004. Interaction Ritual Chains. Oxford: Princeton University Press.

Dant, T. 2004. “The Driver-car.” Theory, Culture \& Society 21 (4/5): 61-80.

Dant, T. 2006. “Material Civilization: Things and Society.” British Journal of Sociology 57 (2): 289-308.

Dant, T., and P.J. Martin. 1999. “By Car: Carrying Modern Society.” Paper presented at Sociality/Materiality: the Status of the Object in Social Science, Brunel University, September 10.

Dawes, G. 2002. “Figure Eights, Spin Outs and Power Slides: Aboriginal and Torres Strait Islander Youth and the Culture of Joyriding.” Journal of Youth Studies 5 (2): 195-208.

Dennis, K., and J. Urry. 2009. After the Car. Cambridge: Polity.

Edensor, T. 2004. “Automobility and National Identity: Representation, Geography and Driving Practice.” Theory, Culture \& Society 21 (4/5): 101-20.

Elias, N. [1939] 1994. The Civilizing Process: Sociogenetic and Psychogenetic Investigations, rev. edn. Oxford: Blackwell.

Elias, N. 1995. “Technization and Civilization.” Theory, Culture \& Society 12 (3): 7-42.

Falconer, R., and S. Kingham. 2007. "Driving People Crazy: A Geography of Boy Racers in Christchurch, New Zealand.” New Zealand Geographer 63: 181-91.

Ferguson, H. 2009. “Driven to Care: The Car, Automobility and Social Work.” Mobilities 4 (2): 275-93. 
Flink, J.J. 1970. America Adopts the Automobile. Cambridge, MA: MIT Press.

Flink, J.J. 1975. The Car Culture. Cambridge, MA: MIT Press.

Foster, M.S. 2003. A Nation on Wheels: The Automobile Culture in America Since 1945.

California: Thomson, Wadsworth.

Franz, K. 2005. Tinkering: Consumers Reinvent the Early Automobile. Philadelphia:

University of Pennsylvania Press.

Freund, P., and G. Martin. 2007. "Hyperautomobility, the Social Organization of Space and Health.” Mobilities 2 (1): 37-49.

Gartman, D. 2004. “Three Ages of the Automobile: The Cultural Logics of the Car.” Theory, Culture \& Society 21 (4/5): 169-96.

Gilroy, P. 2001. “Driving While Black.” In Car Cultures, edited by D. Miller, 81-104.

Oxford: Berg.

Graham, H., and R. White. (2007) “Young People, Dangerous Driving and Car Culture.” Youth Studies Australia 26(3): 28-35.

Graves-Brown, P.M, ed. 2000. Matter, Materiality and Modern Culture. London: Routledge. Hagman, O. 2006. “Morning Queues and Parking Problems: On the Broken Promises of the Automobile.” Mobilities 1 (1): 63-74.

Hagman, O. 2010. “Driving Pleasure: A Key Concept in Swedish Car Culture.” Mobilities 5 (1): 25-39.

Hatton, Z. 2007. The Tarmac Cowboys: An Ethnographic Study of the Cultural World of Boy Racers. PhD diss., University of Plymouth.

Hebdige, D. 1979. Subculture: The Meaning of Style. London: Routledge. Inglis, D. 2004. “Auto-Couture: Thinking the Car in Post-war France.” Theory, Culture \& Society 21(4/5): 197-220.

Katz, J. 1999. How Emotions Work. Chicago, IL: University of Chicago Press. 
Koshar, R. 2004. “Cars and Nations: Anglo-German Perspectives on Automobility between the World Wars.” Theory, Culture \& Society 21 (4/5): 121-44.

Laurier, E., H. Lorimer, B. Brown, O. Jones, O. Juhlin, A. Noble, M. Perry, et al. 2008.

“Driving and "Passengering”: Notes on the Ordinary Organization of Car Travel.” Mobilities 3 (1): 1-23.

Ling, P.J. 1990. America and the Automobile. Manchester: Manchester University Press. Lumsden, K. 2009. ““'Do We Look Like Boy Racers?” The Role of the Folk Devil in Contemporary Moral Panics.” Sociological Research Online 14 (1). doi:10.5153/sro.1840. Lumsden, K. 2012. "Policing the Roads: Traffic Cops, "Boy Racers” and Anti-Social Behaviour.” Policing and Society Advance online publication.

doi:10.1080/10439463.2012.696642

Lumsden, K. 2013. Boy Racer Culture: Youth, Masculinity and Deviance. London: Routledge.

Lupton, D. 1999. “Monsters in Metal Coccoons: “Road Rage” and Cyborg Bodies.” Body \& Society 5 (1): 57-72.

Mennell, S. 1990. “Decivilizing Processes: Theoretical Significance and Some Lines of Research.” International Sociology 5 (2): 205-23.

Mennell, S. 1995. “Technization and Civilization: Introductory Remarks.” Theory, Culture \& Society 12 (3): 1-5.

Merriman, P. 2004. "Driving Places: Marc Augé, Non-places, and the Geographies of England’s M1 Motorway.” Theory, Culture \& Society 21 (4/5): 145-68.

Merriman, P. 2005. “Materiality, Subjectification, and Government: the Geographies of Britain’s Motorway Code.” Environment and Planning D: Society and Space 23: 235-250. Merriman, P. 2006. ““Mirror, Signal, Manoeuvre”: Assembling and Governing the Motorway Driver in Late 1950s Britain.” Sociological Review 54 (1): 75-92. 
Miller, D, ed. 2001. Car Cultures. Oxford: Berg.

Moorhouse, H.F. 1991. Driving Ambitions: An Analysis of the American Hot Rod

Enthusiasm. Manchester: Manchester University Press.

O’Connell, S. 1998. The Car in British Society: Class, Gender and Motoring. Manchester:

Manchester University Press.

O’Dell, T. 2001. "Raggare and the Panic of Mobility: Modernity and Hybridity in Sweden.”

In Car Cultures, edited by D. Miller, 105-32. Oxford: Berg.

Packer, J. 2008. Mobility without Mayhem: Safety, Cars, and Citizenship. Durham, NC: Duke University Press.

Paterson, M. 2007. Automobile Politics: Ecology and Cultural Political Economy. New York: Cambridge University Press.

Rae, B. 1971. The Road and the Car in American Life. Cambridge, MA: MIT Press.

Redshaw, S. 2007. "Articulations of the Car: The Dominant Articulations of Racing and Rally Driving.” Mobilities 2 (1): 121-41.

Redshaw, S., and F. Nicoll. 2010. “Gambling Drivers: Regulating Cultural Technologies, Subjects, Spaces and Practices of Mobility.” Mobilities 5 (3): 409-30.

Scharff, V. 1991. Taking the Wheel: Women and the Coming of the Motor Age. New York: Free Press.

Scottish Executive. 2006. Guidance on Seizure of Vehicles. Edinburgh: Scottish Executive. Sheller, M. 2004. “Automotive Emotions: Feeling the Car.” Theory, Culture \& Society 21 (4/5): 221-42.

Sheller, M., and J. Urry, eds. 2006. Mobile Technologies of the City. London: Routledge. Taylor, N. 2003. “The Aesthetic Experience of Traffic in the Modern City.” Urban Studies 40 (8): 1609-25. 
Thrift, N. 2004. “Driving in the City.” Theory, Culture \& Society 21 (4/5): 41-60.

Urry, J. 2000. “Mobile Sociology.” British Journal of Sociology 51 (1): 185-203.

Urry, J. 2004. “The “System” of Automobility.” Theory, Culture \& Society 21 (4/5): 25-40.

Urry, J. 2007. Mobilities. Cambridge: Polity Press.

Vaaranen, H., and N. Wieloch. 2002. “Car Crashes and Dead End Careers: Leisure Pursuits of the Finnish Subculture of the Kortelliralli Street Racing.” Young: Nordic Journal of Youth Research 10 (1): 42-58.

Wajcman, J. 1991. Feminism Confronts Technology. University Park, PA: University of Pennsylvania State Press.

Warde, A. 2005. “Consumption and Theories of Practice.” Journal of Consumer Culture 5 (2): 131-53.

Wells, H. 2008. “The Techno-Fix Versus the Fair Cop: Procedural (In)Justice and Automated Speed Limit Enforcement.” British Journal of Criminology 48: 798-817.

Wernick, A. 1991. Promotional Culture: Advertising, Ideology and Symbolic Expression. London: Sage. 